\title{
Stereocontrolled formation of substituted imidazolidines in the reaction between $N$-metallated azomethine ylides and isocyanates
}

\author{
Edurne Erkizia, ${ }^{\text {a,1 }}$ Eneko Aldaba, ${ }^{\text {a }}$ Yosu Vara, ${ }^{\text {a }}$ Ana Arrieta, \\ Heinz Gornitzka, ${ }^{b}$ and Fernando P. Cossío ${ }^{\text {a, } *}$ \\ ${ }^{a}$ Kimika Fakultatea, Universidad del País Vasco - Euskal Herriko Unibertsitatea \\ P. K. 1072, 20080 San Sebastián - Donostia, Spain \\ ${ }^{b}$ Laboratoire Hétérochimie Fondamentale et Appliquée, Université Paul Sabatier \\ 118 rue de Narbonne, 31062 Toulouse Cedex 4, France \\ E-mail: fp.cossio@sq.ehu.es
}

\section{Dedicated to Professors José Elguero and Pedro Molina on the occasion of their $70^{\text {th }}$ and $60^{\text {th }}$ birthdays, respectively}

(received 14 Dec 04; accepted 18 Mar 05; published on the web 25 Mar 05)

\begin{abstract}
Substituted imidazolidines (and not imidazolidin-4-ones) are the unexpected cycloadducts obtained in the reaction between imines and isocyanates. The reaction is shown to take place via stepwise [3+2] cycloaddition between the $N$-metallated azomethine ylide formed in situ and the starting imine, followed by nucleophilic addition of the resulting imidazolidine on the $s p$ hybridized carbon atom of the isocyanate. Density-Functional Theory calculations provide a model for the mechanism of this unusual reaction and for the origins of the observed regio- and stereoselectivity.
\end{abstract}

Keywords: Azomethine ylides, imines, isocyanates, imidazolidines, cycloadditions

\section{Introduction}

It is well-known that cumulenes, in particular ketenes and isocyanates, can participate in 1,3dipolar reactions to yield different cycloadducts (Scheme 1). ${ }^{2}$ For example, isocyanates 1 can react with azomethine imines 2 to form 1,2,4-triazolidin-3-ones $\mathbf{6}^{3}{ }^{3}$ In contrast, imines $\mathbf{3}$ react with isocyanates to yield 1,3,5-triazenane-2,4-diones 7 as $[2+2+2]$ cycloadducts. ${ }^{4}$ The reaction between nitrones 4 and isocyanates has also been described. ${ }^{5,6}$ In this case, both the $\mathrm{C}=\mathrm{N}^{5}$ and $\mathrm{C}=\mathrm{O}{ }^{6}$ bonds of the isocyanate can participate in the [3+2] cycloaddition to yield 1,2,4oxazolidin-5-ones 8 and 1,2,4-dioxazolidines 9, respectively. It is noteworthy that the cycloadducts $\mathbf{9}$ have been found as transient species only when chlorosulfonyl isocyanate is used 
as dipolarophile. Finally, it has been reported that stabilized $\mathrm{NH}$-azomethine ylides $\mathbf{5}$ derived from imidates react with isocyanates via the $\mathrm{C}=\mathrm{N}$ bond to yield $1 H$-imidazol-5(4H)-ones 10 as the corresponding $[3+2]$ cycloadducts. $^{7}$

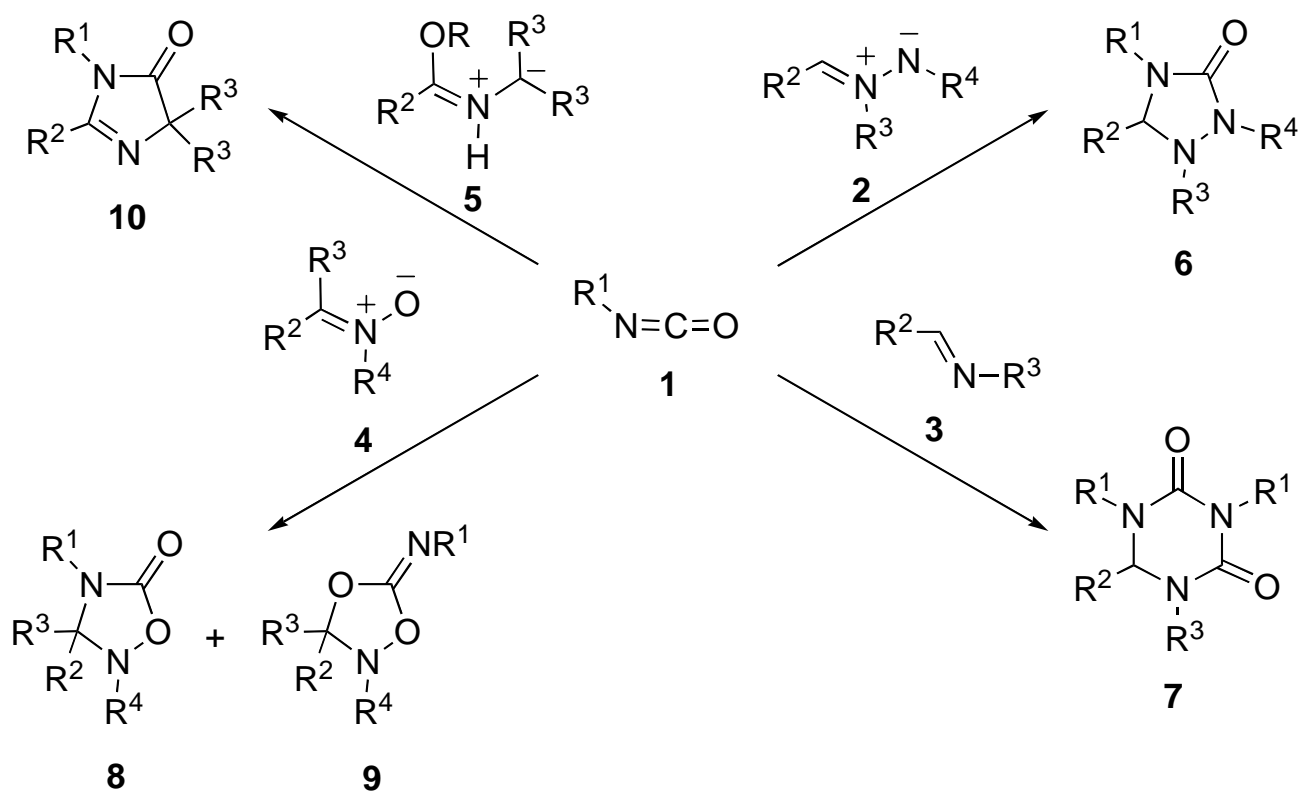

Scheme 1. $[2+2+2]$ and [3+2] cycloadditions between isocyanates and imines and 1,3-dipoles.

Within this context, and as part of our studies on the reactivity of $N$-metallated azomethine ylides toward diverse dipolarophiles, ${ }^{8}$ we decided to explore the reaction between these 1,3 dipoles and isocyanates, as shown in Scheme 2, in order to extend the scope of reactions shown in Scheme 1. However, the outcome of this reaction was found to be completely different.

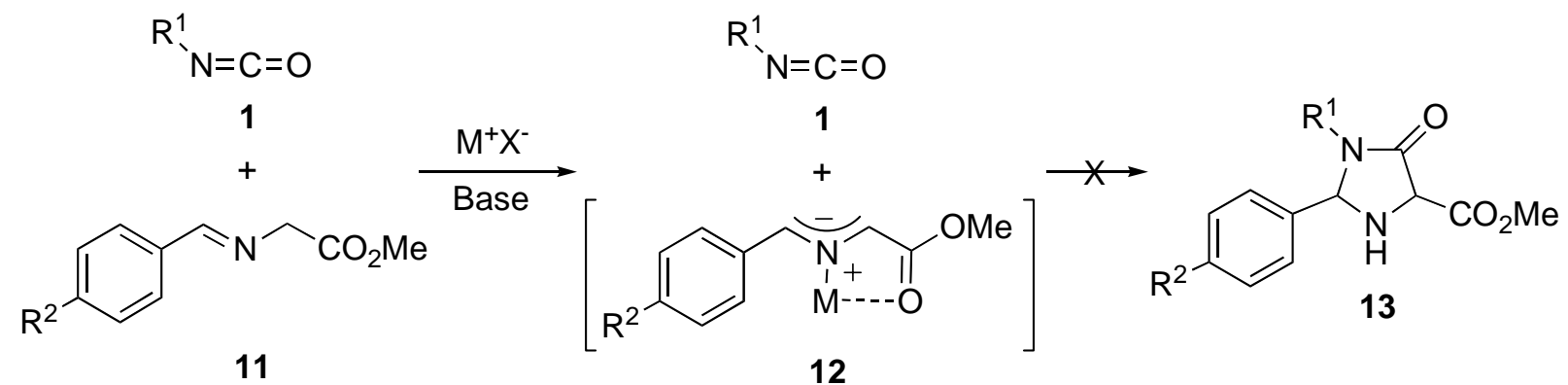

Scheme 2. The expected (but not obtained) cycloadducts 13 resulting from the formal [3+2] cycloaddition between $N$-metallated azomethine ylides 12 and isocyanates $\mathbf{1}$. 


\section{Results and Discussion}

We first studied the reaction in acetonitrile between imine 11a and phenyl isocyanate 1a (Scheme 3) using $\mathrm{AgClO}_{4}$ as metal source and triethylamine as base. The product obtained showed a ${ }^{1} \mathrm{H}-\mathrm{NMR}$ spectrum incompatible with the corresponding imidazolidin-4-one $\mathbf{1 3}$ shown in Scheme 2. Thus, two doublets at $\delta 3.24$ and $3.09 \mathrm{ppm}$ were observed, with a coupling constant of $17.4 \mathrm{~Hz}$. The remaining spectroscopic and analytical data indicated that the structure of cycloadduct 14a was that indicated in Scheme 3. In addition, Molecular Mechanics simulations suggested that the large value of the coupling constant between the methine protons at $\mathrm{C} 4$ and $\mathrm{C} 5$ indicated a cis- $\left(4 S^{*}, 5 S^{*}\right)$ configuration for these carbon atoms.

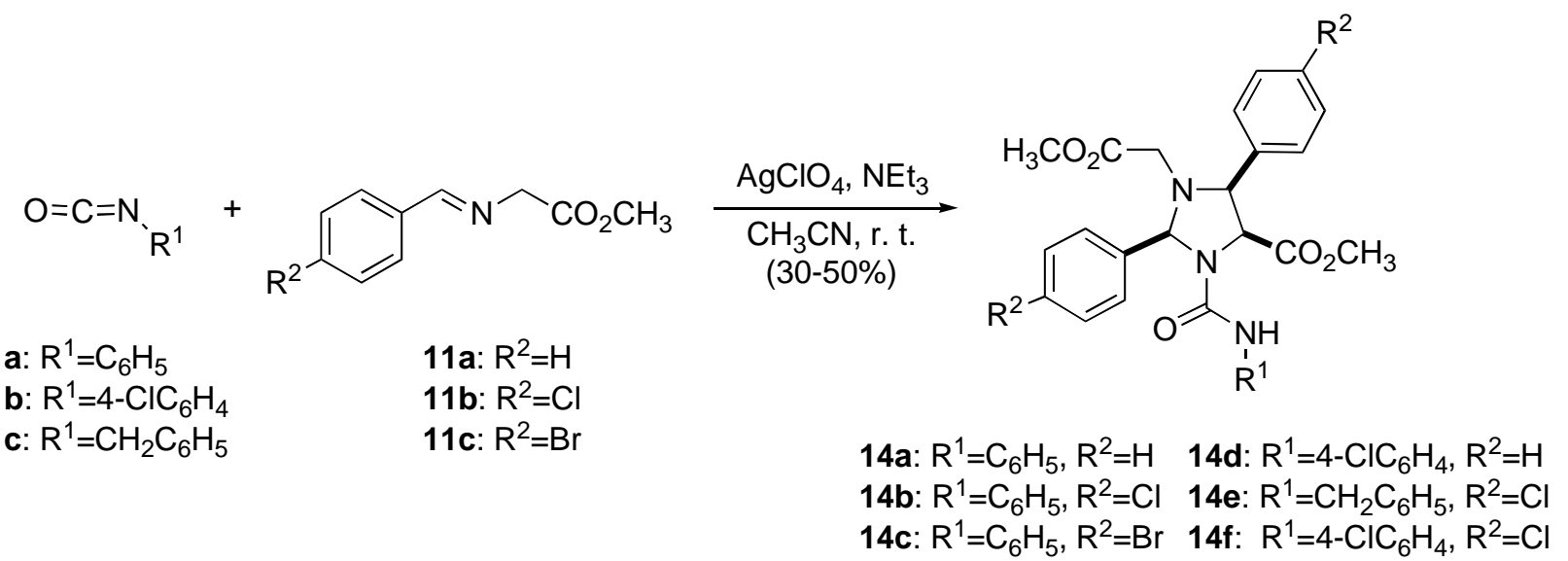

Scheme 3. Imidazolidines 14a-f obtained in the reaction between imines 11a-c and isocyanates 1a-c.

After this first experiment, we performed several analogous reactions using two equivalents of imines 11a-c. In all cases only one regio- and stereoisomer was obtained in low to moderate yields. The relative all- cis $\left(2 S^{*}, 3 S^{*}, 4 S^{*}\right)$ stereochemistry was assigned from the respective ${ }^{1} \mathrm{H}$ NMR spectra (vide supra) and on the basis of the X-ray diffraction analysis ${ }^{9}$ on compound $\mathbf{1 4 \mathbf { b }}$ (Figure 1). Experiments conducted with salts such as $\mathrm{Mg}\left(\mathrm{ClO}_{4}\right)_{2}, \mathrm{MgBr}_{2} . \mathrm{OEt}_{2}$ or $\mathrm{ZnBr}_{2}$ did not improve the yields above those obtained with $\mathrm{AgClO}_{4}$.

In order to elucidate the sequence of events in this cycloaddition we studied the reaction of two equivalents of imine 11b in the presence of one equivalent of $\mathrm{AgClO}_{4}$ and triethylamine (Scheme 4). Under these conditions, the imidazolidine 15a was obtained in 33\% yield. Subsequent reaction with one equivalent of phenyl isocyanate 1a led to the previously obtained compound 14b in good yield (Scheme 4). This result is compatible with a mechanism involving formation of the silver azomethine ylides derived from imines $\mathbf{1 1}$ followed by [3+2] autocyclization with another equivalent of the starting imine. Finally, nucleophilic addition of the $\mathrm{N}$-metallated imidazolidines with isocyanates $\mathbf{1}$ should lead to the corresponding carbamoyl derivatives 14. This mechanism is compatible with the findings of Grigg's group ${ }^{10}$ on the reaction between imines in the presence of metallic salts. 


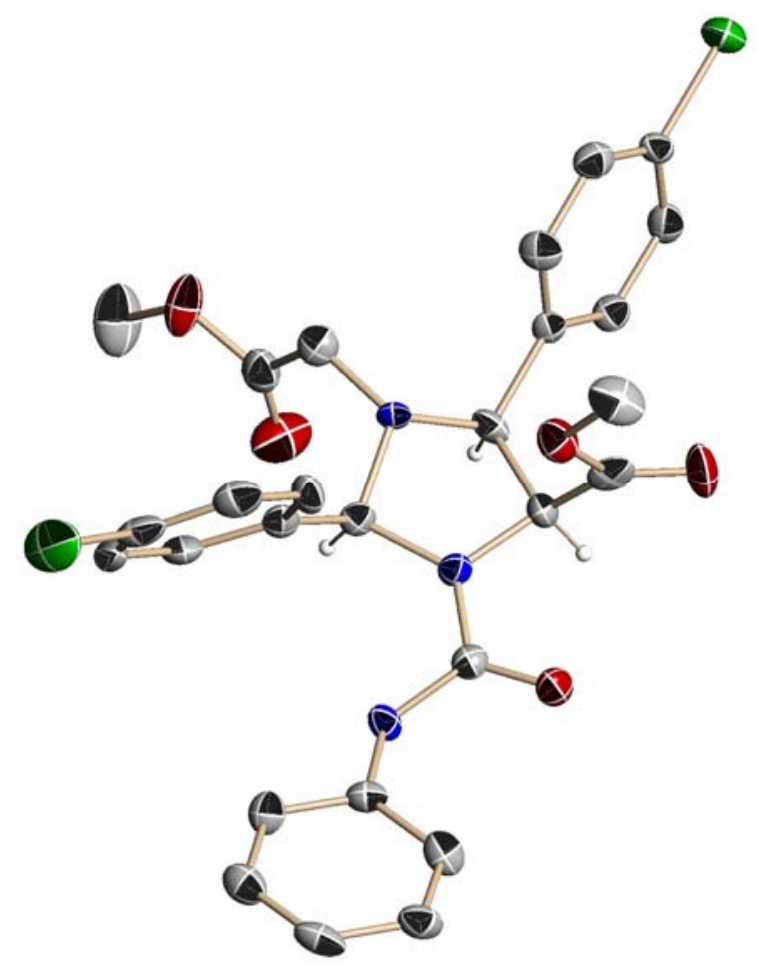

Figure 1. ORTEP diagram (50\% probability ellipsoids) of compound $\mathbf{1 4 b}$ according to the X-ray diffraction analysis. Only the stereochemically relevant hydrogen atoms are shown.

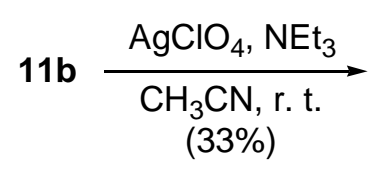

(33\%)<smiles>COC(=O)CN1[C@H](c2ccc(Cl)cc2)N[C@H](C(=O)OC)[C@H]1c1ccc(Cl)cc1</smiles>

$15 a$

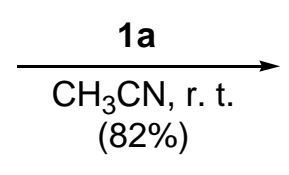

$(82 \%)$<smiles>COC(=O)[C@H]1[C@@H](c2ccc(Cl)cc2)N(CC(=O)[O-])[C@H](c2ccc(Cl)cc2)N1C(=O)Nc1ccccc1</smiles>

Scheme 4. Autocyclization of imine 11b and subsequent formation of derivative 14b in the presence of the isocyanate 1a.

In view of these experimental results, we carried out a computational study using the Density Functional Theory ${ }^{11}$ on the model reaction indicated in Scheme 5 in order to understand the nature of this unusual [3+2] autocyclization. According to our computational results, the reaction mechanism is not concerted, but is stepwise. The main geometric and energetic features of the stationary points (reaction intermediates and transition structures) located and characterized for this model reaction are shown in Figure 2. 


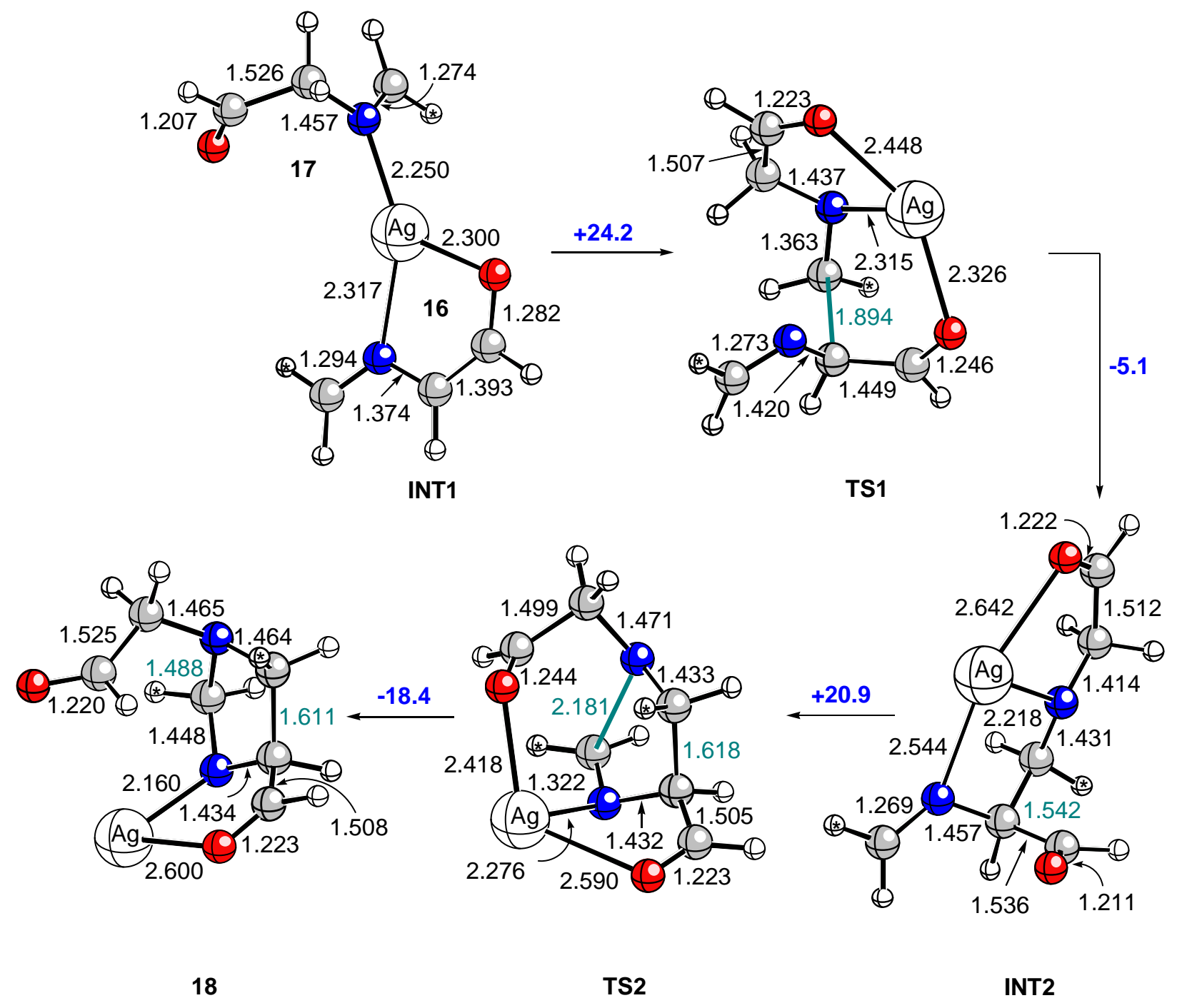

Figure 2. Stationary points (B3LYP/6-31G*\&LANL2DZ level of theory) associated with the reaction shown in Scheme 5. Bond distances are given in $\AA$. Bonds and bond distances corresponding to formation of new sigma bonds are shown in green. Numbers marked in blue are the relative energies (in $\mathrm{kcal} / \mathrm{mol}, \mathrm{B} 3 \mathrm{LYP} / 6-31 \mathrm{G}^{*} \& \mathrm{LANL} 2 \mathrm{DZ}+\Delta \mathrm{ZPVE}$ level of theory) and are shown on the arrows connecting the corresponding stationary points. Unless otherwise stated, hydrogen-, carbon-, nitrogen- and oxygen atoms are represented in white, gray, blue and red, respectively. The asterisks on several hydrogen atoms indicate the position of aryl substituents in substituted (E-) imines of type 11. 


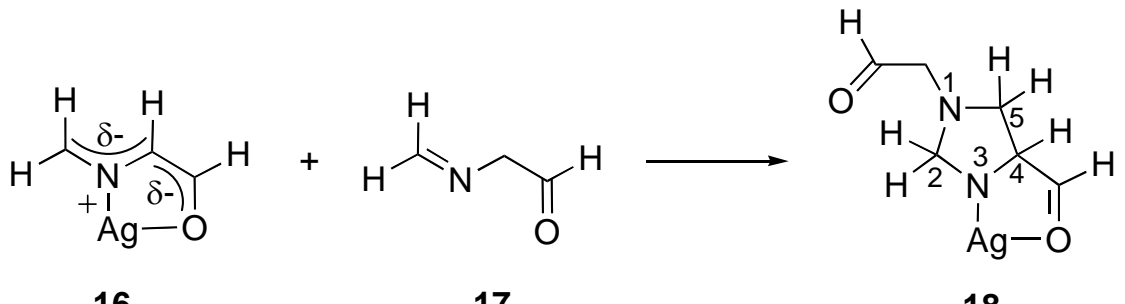

16

17

18

Scheme 5. Model [3+2] cycloaddition between silver azomethine ylide $\mathbf{1 6}$ and imine $\mathbf{1 7}$ to form $N$-metallated imidazolidine 18.

First, we located the intermediate INT1 in which the 1,3-dipole $\mathbf{1 6}$ is coordinated to the silver cation through the nitrogen and the oxygen atoms, whereas the imine sub-unit $\mathbf{1 7}$ is coordinated only by means of the nitrogen atom. The alternative intermediate in which the coordination of the imine 17 takes place via the oxygen atom was calculated to be $5.5 \mathrm{kcal} / \mathrm{mol}$ less stable than INT1. Formation of the C4-C5 bond takes place via TS1, which was found to lie $24.2 \mathrm{kcal} / \mathrm{mol}$ above INT1. This cyclic transition structure has a sofa conformation and shows the geometric features that would be expected for an aldol-like transition state. The next reaction intermediate found in our computed reaction coordinate was INT2, in which the C4-C5 bond is already formed. This intermediate was calculated to lie $5.1 \mathrm{kcal} / \mathrm{mol}$ below TS1 and shows the same coordination pattern as this latter saddle point. Finally, formation of the N1-C2 bond was found to take place via TS2, the calculated activation energy for this second step being ca. 3.3 $\mathrm{kcal} / \mathrm{mol}$ lower than that associated with formation of the $\mathrm{C} 4-\mathrm{C} 5$ bond. This transition structure connects INT2 with the $N$-metallated imidazolidine 18. This latter intermediate leads to the corresponding $\mathrm{NH}$ - imidazolidine analogous to 15a or could alternatively perform the nucleophilic attack on the $s p$ - hybridized carbon atom of the isocyanate $\mathbf{1}$ to yield the corresponding ureas of type 14. It is noteworthy that, according to our computational results, the coordination patterns along the reaction coordinate and the $(E)$-stereochemistry of the starting imines lead to the preferential formation of the all- cis- $\left(2 S^{*}, 4 S^{*}, 5 S^{*}\right)$ cycloadducts, in good agreement with our experimental results (Figure 2).

\section{Conclusions}

In this Paper we report an unusual [3+2] cyclization in the reaction between imines and isocyanates. The proposed mechanism consists of the formation of $N$-metallated azomethine ylides whose stepwise aldol-type reaction with another equivalent of the imine yields the corresponding $\left(2 S^{*}, 4 S^{*}, 5 S^{*}\right)$-imidazolidines. Nucleophilic addition of these cycloadducts on isocyanates leads to the corresponding carbamoyl derivatives. This transformation adds a novel reaction pathway to the well-known [2+2] cycloadditions between cumulenes and imines. ${ }^{2 \mathrm{~b}, 12}$ 


\section{Computational Methods}

All the calculations reported in this paper were performed within the Density Functional Theory, ${ }^{11}$ using the hybrid three-parameter functional customarily denoted as B3LYP. ${ }^{13}$ The standard $6-31 \mathrm{G}^{*}$ basis set ${ }^{14}$ as implemented in the GAUSSIAN $98{ }^{15}$ suite of programs was used to describe hydrogen, carbon, nitrogen and oxygen atoms. Silver atoms were described by the Hay-Wadt effective core potential. ${ }^{16}$ This computational treatment is denoted as B3LYP/6$31 \mathrm{G}^{*} \&$ LANL2DZ. Harmonic analysis on reaction intermediates and transition structures showed that local minima INT1, INT2 and $\mathbf{1 8}$ had positive definite Hessian matrices, whereas both saddle-points TS1 and TS2 had only one imaginary frequency, associated with nuclear motion along the reaction coordinate associated with formation of the $\mathrm{C} 4-\mathrm{C} 5$ and $\mathrm{N} 1-\mathrm{C} 2$ bonds, respectively. Reported differences in energy include zero-point vibration energy corrections, denoted as $\triangle$ ZPVE. The connection between transition structures and local minima was confirmed by Intrinsic Reaction Coordinate (IRC) analysis. ${ }^{17}$

\section{Experimental Section}

General Procedures. Imines 11a-c were prepared as previously reported ${ }^{8 a, b}$ All commercially available compounds were used without further purification (CAUTION: Perchlorates are potentially explosive materials. Under the experimental conditions described below, $\mathrm{AgClO}_{4}$ can be used safely). Acetonitrile was purified according to standard procedures. ${ }^{18}$ Melting points were determined on a Büchi B-540 apparatus and are uncorrected. IR spectra were registered on a Nicolet Magna 560 FTIR spectrophotometer; $v_{\max }\left(\mathrm{cm}^{-1}\right)$ is given for the main absorption bands. ${ }^{1} \mathrm{H}$ - NMR and ${ }^{13} \mathrm{C}$ - NMR spectra were recorded on Bruker Advance 300 and 500 spectrometers, using TMS $\left(\delta_{\mathrm{H}} 0.0 \mathrm{ppm}\right)$ and $\mathrm{CDCl}_{3}\left(\delta_{\mathrm{C}} 76.9 \mathrm{ppm}\right)$ as internal references. Elemental analyses were determined on a Leco CHNS 932 apparatus. All compounds described in this Section are racemic.

\section{General procedure for the preparation of compounds 14a-f}

The imine $11(10 \mathrm{mmol})$ was dissolved in $\mathrm{CH}_{3} \mathrm{CN}(50 \mathrm{~mL})$ and then $\mathrm{NEt}_{3}(0.7 \mathrm{~mL}, 5 \mathrm{mmol})$, $\mathrm{AgClO}_{4}(1.04 \mathrm{~g}, 5 \mathrm{mmol})$ and the isocyanate $1(5 \mathrm{mmol})$ were added. The resulting mixture was stirred under argon overnight and then $\mathrm{Cl}_{2} \mathrm{CH}_{2}(50 \mathrm{~mL})$ was added and the resulting mixture was filtered through a Celite pad. The filtrate was washed with saturated aqueous $\mathrm{NH}_{4} \mathrm{Cl}$ solution $(2 \mathrm{x}$ $20 \mathrm{~mL})$ and water $(4 \times 10 \mathrm{~mL})$. The organic extract was dried with $\mathrm{Na}_{2} \mathrm{SO}_{4}$ and the organic solvent was evaporated under reduced pressure. The resulting residue was triturated and crystallized in $\mathrm{Et}_{2} \mathrm{O}$-hexanes to yield the corresponding adduct 14.

$\left(2 S *, 4 S^{*}, 5 S^{*}\right)$ - Methyl 1-(methoxycarbonyl)methyl-3-(phenylcarbamoyl)-2,5-diphenylimidazolidine-4-carboxylate (14a). Obtained from imine 11a $(1.77 \mathrm{~g}, 10 \mathrm{mmol})$ and phenyl isocyanate 1a $(0.60 \mathrm{~g}, 5 \mathrm{mmol})$. Yield $42 \%$. M.p. $135-137^{\circ} \mathrm{C}$. IR $\left(v, \mathrm{~cm}^{-1}\right)$ : 3400, 1748, 1664, 
1532, 1442, 1207. ${ }^{1} \mathrm{H}$ NMR $\left(\mathrm{CDCl}_{3}, \delta \mathrm{ppm}\right): 8.08-6.90(\mathrm{~m}, 15 \mathrm{H}) ; 6.03(\mathrm{~s}, 1 \mathrm{H}) ; 5.61(\mathrm{~s}, 1 \mathrm{H}) ; 5.02$ $(\mathrm{s}, 2 \mathrm{H}): 3.59(\mathrm{~s}, 3 \mathrm{H}): 3.24(\mathrm{~d}, J=17.4 \mathrm{~Hz}, 1 \mathrm{H}) ; 3.18(\mathrm{~s}, 3 \mathrm{H}) ; 3.09(\mathrm{~d}, J=17.4 \mathrm{~Hz}, 1 \mathrm{H}) .{ }^{13} \mathrm{C}$ NMR $\left(\mathrm{CDCl}_{3}, \delta \mathrm{ppm}\right): 170.86,170.44,152.80,138.46,134.90,130.77,129.78,129.67,128.89$, $128.79,128.74,128.46,123.16,119.36,77.84,64.97,63.72,51.66,45.58$. Anal. Calcd. for $\mathrm{C}_{27} \mathrm{H}_{27} \mathrm{~N}_{3} \mathrm{O}_{5}$ : C, 68.50; H, 5.71; N, 8.88. Found: C, 68.13; H, 5.72; N, $9.00 \%$.

(2S*,4S*,5S*)- Methyl 1-((methoxycarbonyl)methyl)-3-(phenylcarbamoyl)-2,5-bis-(4-chlorophenyl)imidazolidine-4-carboxylate (14b). Obtained from imine 11b (2.11 g, $10 \mathrm{mmol})$ and phenyl isocyanate 1a (0.60 g, 5 mmol). Yield: 43 \%. M.p. $170-171^{\circ} \mathrm{C}$. IR ( $\left(\mathrm{cm}^{-1}\right)$ : 3400, 3332, 1750, 1735 , 1639, 1523, 1440, 1198, 1174. ${ }^{1} \mathrm{H} \operatorname{NMR}\left(\mathrm{CDCl}_{3}, \delta \mathrm{ppm}\right): 8.01(\mathrm{~d}, J=8.2 \mathrm{~Hz}, 2 \mathrm{H}) ; 7.52(\mathrm{~d}, J=$ $8.2 \mathrm{~Hz}, 2 \mathrm{H}) ; 7.35-6.96(\mathrm{~m}, 9 \mathrm{H}) ; 5.94(\mathrm{~s}, 1 \mathrm{H}) ; 5.61(\mathrm{~s}, 1 \mathrm{H}) ; 5.01(\mathrm{~s}, 2 \mathrm{H}) ; 3.62(\mathrm{~s}, 3 \mathrm{H}) ; 3.25(\mathrm{~s}$, $3 \mathrm{H}) ; 3.18(\mathrm{~d}, J=17.9 \mathrm{~Hz}, 1 \mathrm{H}) ; 3.06(\mathrm{~d}, J=17.9 \mathrm{~Hz}, 1 \mathrm{H}) .{ }^{13} \mathrm{C}-\mathrm{NMR}\left(\mathrm{CDCl}_{3}, \delta \mathrm{ppm}\right): 170.78$, $170.16,152.59$, 138.08, 136.94, 134.86, 133.22, 130.93, 130.05, 129.76, 129.07, 128.96, 123.55, 119.50, 76.52, 64.27, 63.50, 51.95, 45.29. Anal. Calcd. for $\mathrm{C}_{27} \mathrm{H}_{25} \mathrm{~N}_{3} \mathrm{O}_{5} \mathrm{Cl}_{2}: \mathrm{C}, 59.78 ; \mathrm{H}, 4.61 ; \mathrm{N}$, 7.75. Found: C, 59.72; H, 4.67; N, $7.84 \%$.

$\left(2 S^{*}, 4 S^{*}, 5 S^{*}\right)-M e t h y l$ 1-(methoxycarbonyl)methyl)-3-(phenylcarbamoyl)-2,5-bis-(4-bromophenyl)imidazolidine-4-carboxylate (14c). Obtained from imine 11c $(2.57 \mathrm{~g}, 10 \mathrm{mmol})$ and phenyl isocyanate 1a $(0.60 \mathrm{~g}, 5 \mathrm{mmol})$. Yield: $50 \%$. M.p. $184-185^{\circ} \mathrm{C}$. IR $\left(\mathrm{v}, \mathrm{cm}^{-1}\right): 3372,1748$, 1740, 1649, 1527, 1442. ${ }^{1} \mathrm{H}$ NMR $\left(\mathrm{CDCl}_{3}, \delta \mathrm{ppm}\right): 7.94$ (d, J=8.2 Hz, 2H), 7.68 (d, J=8.2 Hz, 2H), $7.49(\mathrm{~d}, J=8.1,2 \mathrm{H}), 7.25-6.93(\mathrm{~m}, 7 \mathrm{H}) ; 5.92(\mathrm{~s}, 1 \mathrm{H}), 5.59(\mathrm{~s}, 1 \mathrm{H}) ; 5.02(\mathrm{~d}, J=8.4 \mathrm{~Hz}$, $1 \mathrm{H}) ; 4.97(\mathrm{~d}, J=8.4 \mathrm{~Hz}, 1 \mathrm{H}) ; 3.62(\mathrm{~s}, 3 \mathrm{H}), 3.26(\mathrm{~s}, 3 \mathrm{H}), 3.18(\mathrm{~d}, J=17.8 \mathrm{~Hz}, 1 \mathrm{H}), 3.06(\mathrm{~d}, J=$ $17.8 \mathrm{~Hz}, 1 \mathrm{H}) .{ }^{13} \mathrm{C} \mathrm{NMR}\left(\mathrm{CDCl}_{3}, \delta \mathrm{ppm}\right) 170.75,170.14,152.58,138.06,137.46,133.74,133.02$, 132.03, 131.19, 130.07, 128.95, 125.07, 123.56, 123.01, 119.52, 77.07, 64.34, 63.45, 51.96, 51.74, 45.28. Anal. Calcd. for $\mathrm{C}_{27} \mathrm{H}_{25} \mathrm{~N}_{3} \mathrm{O}_{5} \mathrm{Br}_{2}$ : C 51.36, H 3.96, N, 6.66. Found C 50.64, H 3.97, N $6.63 \%$.

(2S*,4S*,5S*)-Methyl 3-(4-chlorophenylcarbamoyl)-1-((methoxycarbonyl)methyl)-2,5-diphenylimidazolidine-4-carboxylate (14d). Obtained from imine 11a (1.77 g, $10 \mathrm{mmol})$ and 4chlorophenyl isocyanate $\mathbf{1 b}(0.77 \mathrm{~g}, 5 \mathrm{mmol})$. Yield: $30 \%$. M.p. $136-137{ }^{\circ} \mathrm{C} . \mathrm{IR}\left(\mathrm{v}, \mathrm{cm}^{-1}\right): 3409$, 1748, 1734, 1668, 1518, 1212. ${ }^{1} \mathrm{H} \mathrm{NMR}\left(\mathrm{CDCl}_{3}, \delta \mathrm{ppm}\right): 8.06(\mathrm{~d}, J=6.9 \mathrm{~Hz}, 2 \mathrm{H}) ; 7.57-7.53(\mathrm{~m}$, $3 \mathrm{H}) ; 7.37-7.32(\mathrm{~m}, 5 \mathrm{H}) ; 7.08(\mathrm{~d}, J=8.8 \mathrm{~Hz}, 2 \mathrm{H}) ; 6.86(\mathrm{~d}, J=8.8 \mathrm{~Hz}, 2 \mathrm{H}) ; 6.02(\mathrm{~s}, 1 \mathrm{H}) ; 5.62(\mathrm{~s}$, $1 \mathrm{H}) ; 5.02(\mathrm{~d}, J=8.8 \mathrm{~Hz}, 1 \mathrm{H}) ; 5.01(\mathrm{~d}, J=8.8 \mathrm{~Hz}, 1 \mathrm{H}) ; 3.60(\mathrm{~s}, 3 \mathrm{H}) ; 3.25(\mathrm{~d}, J=17.7 \mathrm{~Hz}, 1 \mathrm{H})$; $3.19(\mathrm{~s}, 3 \mathrm{H}) ; 3.10(\mathrm{~d}, J=17.7 \mathrm{~Hz}, 1 \mathrm{H}) .{ }^{13} \mathrm{C} \mathrm{NMR}\left(\mathrm{CDCl}_{3}, \delta \mathrm{ppm}\right): 170.77,170.42,152.59$, $138.32,137.07,134.78,130.89,129.85,129.65,128.96,128.78,128.45,128.08,120.49,77.78$, 64.94, 63.72, 51.72, 51.53, 45.51. Anal. Calcd. for $\mathrm{C}_{27} \mathrm{H}_{26} \mathrm{~N}_{3} \mathrm{O}_{5} \mathrm{Cl}$ : C 63.84, H 5.12, N, 8.23. Found C 63.22, H 5.20, N $8.10 \%$.

$\left(2 S^{*}, 4 S^{*}, 5 S^{*}\right)$-Methyl 3-(benzylcarbamoyl)-1-((methoxycarbonyl)methyl)-2,5-bis(4-chlorophenyl)imidazolidine-4-carboxylate (14e). Obtained from imine 11b (2.11 g, $10 \mathrm{mmol})$ and benzyl isocyanate 1c $(0.65 \mathrm{~g}, 5 \mathrm{mmol})$. Yield: 47 \%. M.p. $185-187^{\circ} \mathrm{C}$. IR $\left(\mathrm{v}, \mathrm{cm}^{-1}\right): 3436,3339$, 1752, 1726, 1629, 1532, 1491, 1209. ${ }^{1} \mathrm{H} \mathrm{NMR}\left(\mathrm{CDCl}_{3}, \delta \mathrm{ppm}\right): 7.88(\mathrm{~d}, J=8.3 \mathrm{~Hz}, 2 \mathrm{H}) ; 7.39$ (d, $J=8.3 \mathrm{~Hz}, 2 \mathrm{H}) ; 7.32(\mathrm{~d}, J=8.3 \mathrm{~Hz}, 2 \mathrm{H}) ; 7.28(\mathrm{~d}, J=8.3 \mathrm{~Hz}, 2 \mathrm{H}) ; 7.25-7.20(\mathrm{~m}, 3 \mathrm{H}) ; 6.86\left(\mathrm{~d}_{\mathrm{b}}, J\right.$ $=5.9 \mathrm{~Hz}, 2 \mathrm{H}) ; 5.44(\mathrm{~s}, 1 \mathrm{H}) ; 4.95(\mathrm{~d}, J=8.4 \mathrm{~Hz}, 1 \mathrm{H}) ; 4.91(\mathrm{~d}, J=8.4 \mathrm{~Hz}, 1 \mathrm{H}) ; 4.28(\mathrm{dd}, J=13.8$ 
$\left.\mathrm{Hz}, \mathrm{J}^{\prime}=5.0 \mathrm{~Hz}, 1 \mathrm{H}\right) ; 4.18-4.12(\mathrm{~m}, 2 \mathrm{H}) ; 3.59(\mathrm{~s}, 3 \mathrm{H}) ; 3.24(\mathrm{~s}, 3 \mathrm{H}) ; 3.13(\mathrm{~d}, J=17.8 \mathrm{~Hz}, 1 \mathrm{H})$; $3.03(\mathrm{~d}, J=17.8 \mathrm{~Hz}, 1 \mathrm{H}) .{ }^{13} \mathrm{C} \mathrm{NMR}\left(\mathrm{CDCl}_{3}, \delta \mathrm{ppm}\right): 171.02,170.20,155.04,138.526,137.35$, $136.24,134,79,133.46,130.77,129.78,129.70,129.01,128.63,127.35,127.16,77.58,64.52$, 63.68, 51.80, 51.61, 45.43, 44.72. Anal. Calcd. for $\mathrm{C}_{28} \mathrm{H}_{27} \mathrm{~N}_{3} \mathrm{O}_{5} \mathrm{Cl}_{2}: \mathrm{C} 60.43, \mathrm{H}$ 4.86, N 7.55. Found C, 60.10, H 4.92, N, $7.63 \%$.

$\left(2 S^{*}, 4 S^{*}, 5 S^{*}\right)$-Methyl 3-(4-chlorophenylcarbamoyl)-1-((methoxycarbonyl)methyl)-2,5-bis(4-chlorophenyl)imidazolidine-4-carboxylate (14f). Obtained from imine 11b (2.11 g, $10 \mathrm{mmol})$ and 4-chlorophenyl isocyanate $1 \mathrm{~b}(0.77 \mathrm{~g}, 5 \mathrm{mmol})$. Yield: $31 \%$. M.p. $170-172{ }^{\circ} \mathrm{C}$. IR $\left(v, \mathrm{~cm}^{-1}\right): 3391,3325,1749,1739,1640,1522,1485,1202,1169,1085,1014 .{ }^{1} \mathrm{H}-\mathrm{NMR}\left(\mathrm{CDCl}_{3}\right.$, $\delta$ ppm): $8.01(\mathrm{~d}, J=7.4 \mathrm{~Hz}, 2 \mathrm{H}) ; 7.53(\mathrm{~d}, J=7.4 \mathrm{~Hz}, 2 \mathrm{H}) ; 7.34(\mathrm{~d}, J=7.6 \mathrm{~Hz}, 2 \mathrm{H}) ; 7.30(\mathrm{~d}, J=$ $7.6 \mathrm{~Hz}, 2 \mathrm{H}) ; 7.11(\mathrm{~d}, J=8.3 \mathrm{~Hz}, 2 \mathrm{H}) ; 6.92(\mathrm{~d}, J=8.3 \mathrm{~Hz}, 2 \mathrm{H}) ; 5.93(\mathrm{~s}, 1 \mathrm{H}) ; 5.61(\mathrm{~s}, 1 \mathrm{H}) ; 5.0$ (d, $J=8.9 \mathrm{~Hz}, 1 \mathrm{H}) ; 4.99(\mathrm{~d}, J=8.9 \mathrm{~Hz}, 1 \mathrm{H}) ; 3.62(\mathrm{~s}, 3 \mathrm{H}) ; 3.25(\mathrm{~s}, 3 \mathrm{H}) ; 3.18(\mathrm{~d}, J=18.0 \mathrm{~Hz}, 1 \mathrm{H})$; $3.06(\mathrm{~d}, J=18.0 \mathrm{~Hz}, 1 \mathrm{H}) .{ }^{13} \mathrm{C}-\mathrm{NMR}\left(\mathrm{CDCl}_{3}, \delta \mathrm{ppm}\right): 170.64,170.10,152.40,136.89,136.82$, $136.75,134.93,133.13,130.91,130.08,129.75,129.08,128.91,128.47,77.06,64.33,63.51$, 51.94, 51.70, 45.31. Anal. Calcd. for $\mathrm{C}_{27} \mathrm{H}_{24} \mathrm{~N}_{3} \mathrm{O}_{5} \mathrm{Cl}_{3}$ : C 56.20, H 4.16, N 7.28. Found: C 55.95, H $4.20, \mathrm{~N}, 7.33 \%$.

$\left(2 R^{*}, 4 S^{*}, 5 S^{*}\right)$-Methyl 1-(methoxycarbonyl)methyl)-2,5-bis(4-chlorophenyl)imidazolidine-4carboxylate (15a). The imine 11a $(1.76 \mathrm{~g}, 10 \mathrm{mmol})$ was dissolved in $\mathrm{CH}_{3} \mathrm{CN}(50 \mathrm{~mL})$ and then $\mathrm{NEt}_{3}(0.7 \mathrm{~mL}, 5 \mathrm{mmol})$ and $\mathrm{AgClO}_{4}(1.04 \mathrm{~g}, 5 \mathrm{mmol})$ were added. The resulting mixture was stirred under argon overnight and then $\mathrm{Cl}_{2} \mathrm{CH}_{2}(50 \mathrm{~mL})$ was added and the resulting mixture was filtered through a Celite pad. The filtrate was washed with saturated aqueous $\mathrm{NH}_{4} \mathrm{Cl}$ solution $(2 \mathrm{x}$ $20 \mathrm{~mL}$ ) and water $(4 \times 10 \mathrm{~mL})$. The organic extract was dried with $\mathrm{Na}_{2} \mathrm{SO}_{4}$ and the organic solvent was evaporated under reduced pressure. The resulting oily residue was purified by flash chromatography (Silica gel 70-230 mesh, 1:5 mixture of AcOEt-hexanes as eluent) to yield the corresponding the title product. Yield: $33 \%$. Colorless oil. IR $\left(\mathrm{v}, \mathrm{cm}^{-1}\right): 3296,1738,1487,1437$, 1211, 1176, 1095, 1020. ${ }^{1} \mathrm{H}-\mathrm{NMR}\left(\mathrm{CDCl}_{3}, \delta \mathrm{ppm}\right): 7.58$ (d, $\left.J=8.2 \mathrm{~Hz}, 2 \mathrm{H}\right) ; 7.40(\mathrm{~d}, J=8.2 \mathrm{~Hz}$, 2H); 7.32-7.25 (m, 4H); 5.03, (s, 1H); $4.63(\mathrm{~d}, J=9.3 \mathrm{~Hz}, 1 \mathrm{H}) ; 4.32(\mathrm{~d}, J=9.3 \mathrm{~Hz}, 1 \mathrm{H}) ; 3.54$ (s, $3 \mathrm{H}) ; 3.26(\mathrm{~d}, J=17.3 \mathrm{~Hz}, 1 \mathrm{H}) ; 3.20(\mathrm{~s}, 3 \mathrm{H}) ; 3.17$ (d, $J=17.3 \mathrm{~Hz}, 1 \mathrm{H}) ; 2.95(\mathrm{~s}, 1 \mathrm{H}) .{ }^{13} \mathrm{C}-\mathrm{NMR}$ $\left(\mathrm{CDCl}_{3}, \delta \mathrm{ppm}\right): 171.49,170.68,137.24,136.88,135.08,133.88,129.53,129.47,129.22$, $128.47,79.26,66.75,64.65,51.90,51.47,47.60$. The title compound 15a $(2.11 \mathrm{~g}, 5 \mathrm{mmol})$ was transformed into a solid derivative by means of reaction with phenyl isocyanate $1 \mathrm{a}(0.60 \mathrm{~g}$, $5 \mathrm{mmol})$ in $\mathrm{CH}_{3} \mathrm{CN}(50 \mathrm{~mL})$ overnight at room temperature and under argon atmosphere. The above-described workup and crystallization in $\mathrm{Et}_{2} \mathrm{O}$-hexanes gave a product (Yield: $82 \%$ ) whose analytical properties were identical to those found for compound $\mathbf{1 4 b .}$ 


\section{Acknowledgements}

This work has been supported by the Universidad del País Vasco - Euskal Herriko Unibertsitatea, by the Gobierno Vasco - Eusko Jaurlaritza (Grant 9/UPV00170.21513548/2001), by Dominion Pharmakine Ltd. and by the Spanish Ministerio de Educación y Ciencia (Project BQU2001-0904). E. E. and E. A. thank the Gobierno Vasco - Eusko Jaurlaritza for their respective postdoctoral and predoctoral fellowships. Y. V. also thanks the Ministerio de Educación y Ciencia for his predoctoral fellowship.

\section{References and Notes}

1. Present address: Labein Fundazioa, Parque Tecnológico de Bizkaia, Edificio 700, 48160 Derio (Vizcaya), Spain.

2. (a) Huisgen, R. Angew. Chem., Int. Ed. 1963, 2, 565. (b) Tidwell, T. T. Ketenes; Wiley: New York, 1995; pp 536-544.

3. (a) Bedel, O.; Urban, D.; Langlois, Y. Tetrahedron Lett. 2002, 43, 607. (b) Bast, K.; Behrens, M.; Durst, T.; Grashey, R.; Huisgen, R.; Schiffer, R.; Temme, R. Eur. J. Org. Chem. 1998, 379.

4. (a) Tietz, H.; Rademacher, O.; Zahn, G. Eur. J. Org. Chem. 2000, 2105. (b) Giesecke, H.; Hocker, J. Synthesis 1977, 806. (c) Richter, R.; Ulrich, H. J. Org. Chem. 1971, 36, 2005.

5. (a) Matsuoka, T.; Harano, K. Tetrahedron 1995, 51, 6451. (b) van der Broek, L. A. G. M. Tetrahedron 1996, 52, 4467.

6. (a) Joseph, S. P.; Dhar, D. N. Tetrahedron 1986, 42, 5979. (b) Joseph, S. P.; Dhar, D. N. Tetrahedron 1988, 44, 5209.

7. Lerestif, J. M.; Toupet, L.; Sinbandhit, S.; Tonnard, F.; Bazureau, J. P.; Hamelin, J. Tetrahedron 1997, 53, 6351.

8. (a) Vivanco, S.; Lecea, B.; Arrieta, A.; Prieto, P.; Morao, I.; Linden, A.; Cossío, F. P. J. Am. Chem. Soc. 2000, 122, 6078. (b) Ayerbe, M.; Arrieta, A.; Cossío, F. P.; Linden, A. J. Org. Chem. 1998, 63, 1795. (c) Zubia, A.; Mendoza, L.; Vivanco, S.; Aldaba, E.; Carrascal, T.; Lecea, B.; Arrieta, A.; Vidal-Vanaclocha, F. Cossío, F. P. Angew. Chem., Int. Ed. In press.

9. Crystal data for 14b: $\mathrm{C}_{27} \mathrm{H}_{25} \mathrm{Cl}_{2} \mathrm{~N}_{3} \mathrm{O}_{5}, \mathrm{M}=542.40$, triclinic, $P 1, a=10.266(1) \AA, b=$ 10.351(1) $\AA, c=13.038(1) \AA, \alpha=97.610(2)^{\circ}, \beta=110.104(2)^{\circ}, \gamma=90.809(2)^{\circ}, V=$ 1287.0(2) $\AA^{3}, \mathrm{Z}=2.5765$ reflections (4635 independent, $\left.R_{\text {int }}=0.0322\right)$ were collected at low temperatures $(T=173(2) \mathrm{K})$ using an oil-coated shock-cooled crystal on a Bruker-AXS CCD 1000 diffractometer with MoK $\alpha$ radiation $(\lambda=0.71073 \AA)$. The structure was solved by direct methods (SHELXS-97) ${ }^{19}$ and all non hydrogen atoms were refined anisotropically using the least-squares method on $F^{2}{ }^{20}$ Largest electron density residue: 0.228 e $\AA^{-3}, R_{1}$ (for $I>2 \sigma(I))=0.0446$ and $w R_{2}=0.0900$ (all data) with $R_{1}=\Sigma|| F_{o}|-| F_{c}|| \Sigma\left|F_{o}\right|$ and $w R_{2}=(\Sigma w$ $\left.\left(F_{o}^{2}-F_{c}{ }^{2}\right)^{2} / \Sigma w\left(F_{o}^{2}\right)^{2}\right)^{0.5}$. The absolute structure parameter refines to a value of $0.06(7){ }^{21}$ 
CCDC 258275 contains the supplementary crystallographic data for this paper. These data can be obtained free of charge via http://www.ccdc.cam.ac.uk/data request/cif, by emailing to data request@ccdc.cam.ac.uk or by contacting The Cambridge Crystallographic Data Centre, 12, Union Road, Cambridge CB2 1EZ, UK; fax: +44 1223336033.

10. Amornraksa, K.; Barr, D.; Donegan, G.; Grigg, R.; Ratananukul, P.; Sridharan, V. Tetrahedron 1989, 45, 4649. For another recent example of [3+2] dimerization of imines see: Pearson, W. H.; Walters, M. A.; Rosen, M. K.; Harter, W. G. ARKIVOC, 2002, (viii), 91.

11. Parr, R. G.; Yang, W. Density-Functional Theory of Atoms and Molecules; Oxford University Press: New York, 1989.

12. Ghosez, L.; Marchand-Brynaert, J. In Comprehensive Organic Chemistry, Trost, B. M.; Fleming, L., Eds; Pergamon Press: Oxford, 1991; Vol. 5, pp 86-89.

13. (a) Kohn, W.; Becke, A. D.; Parr, R. G.; J. Phys. Chem. 1996, 100, 12974. (b) Becke, A. D. J. Chem. Soc. 1993, 98, 5648. (c) Becke, A. D. Phys. Rev. A 1988, 38, 3098.

14. Hehre, W. J.; Radom, L.; Schleyer, P. v. R.; Pople, J. A. Ab Initio Molecular Orbital Theory; Wiley: New York, 1986; pp. 76-87 and references therein.

15. Gaussian 98, Revision A.5, Frisch, M. J.; Trucks, G. W.; Schlegel, H. B.; Scuseria, G. E.; Robb, M. A.; Cheeseman, J. R.; Zakrzewski, V. G.; Montgomery, Jr., J. A.; Stratmann, R. E; Burant, J. C.; Dapprich, S.; Millam, J. M.; Daniels, A. D.; Kudin, K. N.; Strain, M. C.; Farkas, O.; Tomasi, J.; Barone, V.; Cossi, M.; Cammi, R.; Mennucci, B; Pomelli, C.; Adamo, C.; Clifford, S.; Ochterski, J.; Petersson, G. A.; Ayala, P. Y.; Cui, Q; Morokuma, K.; Malick, D. K.; Rabuck, A. D.; Raghavachari, K.; Foresman, J. B.; Cioslowski, J.; Ortiz, J. V.; Stefanov, B. B.; Liu, G.; Liashenko, A.; Piskorz, P.; Komaromi, I.; Gomperts, R.; Martin, R. L.; Fox, D. J.; Keith, T.; Al-Laham, M. A.; Peng, C. Y.; Nanayakkara, A.; Gonzalez, C.; Challacombe, M.; Gill, P. M. W.; Johnson, B.; Chen, W.; Wong, M. W.; Andres, J. L.; Gonzalez, C.; Head-Gordon, M.; Replogle, E. S.; Pople, J. A., Gaussian, Inc., Pittsburgh PA, 1998.

16. Hay, P. J.; Wadt, W. R. J. Chem. Phys. 1985, 82, 299.

17. (a) Fukui, K. Acc. Chem. Res. 1981, 14, 363. (b) Gonzalez, C.; Schlegel, H. B. J. Chem. Phys. 1989, 90, 2154. (c) Gonzalez, C.; Schlegel, H. B. J. Phys. Chem. 1990, 94, 5523.

18. Armarego, W. L. F.; Perrin, D. D. Purification of Laboratory Chemicals, $4^{\text {th }}$ Ed.; Butterworth-Heinemann: Oxford, 1996.

19. Sheldrick, G. M. Acta Crystallogr. 1990, A46, 467.

20. SHELXL-97, Program for Crystal Structure Refinement, Sheldrick, G. M., University of Göttingen, 1997.

21. Flack, H. D. Acta Crystallogr. Sect. A. 1983, 39, 876. 